\title{
EFFECTS OF EU EXPANSION ON MIGRANTS' EMPLOYMENT AND INCOME: A NATURAL EXPERIMENT
}

\section{Jan-Jan Soon*}

\begin{abstract}
With the European Union expansion in 2004 providing a unique form of natural experiment, this paper uses the European Values Study data and the difference-in-differences estimation to identify causal effects of the EU expansion on migrants' employment chances and income. Estimation results suggest that the expansion has increased migrants' employment chances and income. The probability of having a full-time employment for a male migrant in the postexpansion period increases by about 7.7 percentage points. The increase in income for male migrants is higher than that of their female counterparts after the expansion. When the income distribution is broken down into quantiles, estimation results show that male migrants at lower ends of the income distribution experience higher increase in income. At the highest end of the income distribution, there is no evidence that the expansion has any significant effect on either male or female migrants' income.
\end{abstract}

Keywords: European Union expansion, migrant, employment, income, difference-in-differences, quantile regression, natural experiment

JEL Classification: C21, J15, J61

\section{Introduction}

In 2004, the European Union (EU) experienced its largest expansion, with 10 new member countries (EU10) joining its existing 15 member countries (EU15). Access to the EU signifies free geographical movement and thereby, more flexibility in job mobility. This would likely bring about higher chances of getting better employment and higher income. Free geographical movement and equal treatment in employment among EU citizens are parts of the basic principles enshrined in the the EU Accession Treaty. The European Commission reported that five years after the 2004 EU expansion, economic growth in the new EU10 countries has jumped from an average of 3.5\% in the 1999-2003 pre-expansion period to an average of 5.5\% in the 2004-2008 post-expansion period. Employment growth in new EU10 countries also saw a 1.5\% increase annually in the same post-expansion period, along with strong job creation in EU15 countries. In 2007, the unemployment rate in new EU10 countries dropped to $7.6 \%$, down by 5 percentage points from its 2003 level. Between 2004 and 2007, net job creation in all EU member countries (EU27) amounted to12.2 million jobs, compared with 2.2 million new jobs over the period 2001-2004

* Jan-Jan Soon, School of Economics, Finance and Banking, University Utara Malaysia, Malaysia. (soon@uum.edu.my).

I am grateful to Hessel Oosterbeek, Erik Plug, and Adam Booij for their generous and insightful comments. 
(European Commission, 2009). After the expansion, per capita income in EU10 countries rose from an average of $44 \%$ of the EU15 countries' level in 1997 to more than $50 \%$ in 2005 (European Commission, 2006a).

As an aside, even at the onset of the 2008 global economic crisis, the picture was not all bleak for the EU migrants though some migrant groups in different EU countries were affected differently by the crisis. In terms of unemployment, the migrant groups hardest hit by the crisis were those in low-skilled jobs, and those in construction and manufacturing sectors (Papademetriou et al., 2010). In 2009, some major migrant-recruiting EU countries were still receiving migrant labour, especially the skilled migrants (Koehler et al., 2010). In Portugal and Spain, migrants from EU10 countries were still arriving in large numbers (Bräuninger and Majowski, 2011).

Comprehensive comparative studies on the effects of EU expansion on migrants' labour market outcomes are abound, such as those by Dustmann and Frattini (2011), Dobson (2009), Drinkwater et al. (2009), Blanchflower and Lawton (2008), and Bauer and Zimmermann (1999). These studies, however, are not based on a causal inference framework. Their findings therefore are correlational, i.e. no causal interpretation could be derived. In the migration literature, Card's (1990) work is perhaps the best-known pioneer in exploiting a natural experiment to study the causal effects of migration, i.e. the effects of a sudden influx of migrants from Cuba on Miami's labour market. Card exploited, as a natural experiment, the declaration in April 1980 by the Cuban government in allowing any Cubans wishing to migrate to the United States to freely leave from the Mariel Port between April and October 1980. It is aptly known thereafter as the Mariel Boatlift. By the end of the Mariel Boatlift's period, approximately 125,000 Cuban immigrants had landed in Miami. Card found that the Miami labour market was able to absorb the huge immigrant influx; the Miami labour force actually increased by $7 \%$ during that period, with no evidence of undesirable effects on wages or unemployment rates.

Despite the relative importance of labour market outcomes, particularly those of the migrants', there are surprisingly few empirical studies looking at how such outcomes are affected by the EU expansion within a causal inference framework; following there are some notable exceptions. Applying the difference-in-differences (DD) approach on a panel data set at the aggregate level of West German counties, Buettner and Rincke (2007) estimated the causal effects of the Berlin Wall removal on the West German local residents' employment and wages; the Berlin Wall removal draws an analogy with the EU expansion. On the contrary, by using a household-level micro data set, Elsner (2013) looked at the causal effect of the 2004 EU expansion on the wages of non-migrants in Eastern European sending countries. Causal model frameworks have also been used in empirical studies looking at the effects of the EU expansion on some other aspects, such as on migration flows (Pytlikova, 2014; Pedersen and Pytlikova, 2008), on criminal behaviour (Mastrobuoni and Pinotti, 2011), on the performance of service enterprises (Braakmann and Vogel, 2010), and on border cities' population growth (Brakman et al., 2012).

The main objective of this paper is to estimate causal effects of the 2004 EU expansion on migrants' employment and income. A DD estimation strategy is used to identify such 
effects. It is hypothesized the EU expansion would result in migrants having better chances of working in full-time employment and getting higher income. With the EU expansion allowing for more flexible labour mobility, what does it entail for the migrants in terms of employment chances and income? Are there any significant effects of the expansion on their labour market outcomes? If yes, what are the magnitudes of the effects? These are the questions this paper answers.

\section{Data}

This paper uses data from the European Values Study (EVS). The EVS is a comprehensive survey conducted throughout European countries on human values such as values towards family, work, and society. Four waves of EVS surveys have been conducted starting from 1981 with a 9-year interval with the most recent wave of survey completed in 2008 . They are cross-sectional surveys, with 16 countries participating in the 1981 wave, 29 countries in 1990, 33 in 1999, and 47 in 2008. Respondents are selected from the adult population of 18 years and older using a stratified random sampling design. A total of 1,500 respondents are selected for each participating country.

The empirical analysis in this paper uses the EVS1999 and EVS2008 data sets, as they straddle the 2004 EU expansion year. The working data set merges the EVS2008 and EVS1999 data sets forming a pooled cross-section. By 2004, there are 25 countries forming the EU, in which 10 of them joined in 2004. In using the pooled data set, however, only 24 countries (EU24) are included in the paper's analyses because the EVS1999 dataset does not contain any data for Cyprus. Prior to merging, each dataset is cleaned such that it includes both citizens and migrants in the EU24 countries. Citizens and migrants here are defined in the context of a country, and not in the EU as a whole, i.e. a citizen does not mean an EU citizen, but a citizen of a particular EU country. Analogously, a migrant is defined as an individual originating from one of the EU24 countries and residing in another EU country with migrant status.

To clean the EVS2008 dataset, it first involves discarding observations, in which the host countries are not any of the EU24 countries. To allow for merging with EVS1999, observations with Cyprus as the host country are also discarded. The second step involves discarding observations who are not citizens of any of the EU24 countries. The information on citizen status is retrieved from a question in EVS2008 that asks for the respondent's nationality or citizenship, where nationality equates having a country's passport. These two steps ensure that any remaining observations in the EVS2008 dataset consist of citizens and migrants in the EU24 countries. Examples of discarded observations are such as: (i) a respondent with Russian nationality residing in Spain, or (ii) a respondent with Italian nationality residing in Norway. In these examples, the irrelevant observations are discarded because Russia and Norway are not part of the EU countries.

The first step in cleaning the EVS1999 dataset is the same as described above. There is, however, no question in EVS1999 soliciting respondents' nationality. This poses a problem because the dataset might include irrelevant observations such as those given 
in the preceding two examples. To somewhat circumvent this problem, a crude proxy is used. The language used during interview is used to proxy respondents' nationalities, since it is reasonably plausible that respondents are most comfortable using their national language. For example, there are 178 and 245 respondents residing in Estonia and Latvia who were interviewed in Russian. These respondents are subsequently discarded from the data set, in an analogous second step as in EVS2008. The final working dataset is therefore a two-year pooled cross-section containing (i) observations from EU15 and EU9 (i.e. with Cyprus excluded from EU10) countries, (ii) those with citizen status in the EU24 countries before and after the 2004 EU expansion, and (iii) those with migrant status in the EU24 countries before and after the expansion.

A caveat to note is that due to data limitation, the empirical analyses in this paper do not take into consideration transitional restrictions applied by different EU15 countries on migrants from EU10 countries. Put in place to guard against threats to domestic labour markets, these transitional restrictions, however, do not apply to two EU10 countries Cyprus and Malta. These restrictions allow EU15 countries to open up their labour markets gradually following a ' $2+3+2$ years' arrangement. Based on this arrangement, EU15 countries review their labour market situations and decide whether to keep the restrictions in place within the first two years upon the EU expansion. This is followed by another round of review in the next three years, and one final round in the next two years. Three EU15 countries - the UK, Ireland, and Sweden - do not have any transitional restrictions. During the course of the seven years after the 2004 EU expansion, different EU15 countries opened up their labour markets at different points of time, and also for different job sectors and certain types of professions. Some EU15 countries such as Austria and Germany only lifted the restrictions by May 2011, i.e. at the end of the seven-year transitional restriction period. Furthermore, reciprocal restrictions are also allowed, i.e. the new EU10 countries can impose similar labour market restrictions on migrants from EU15 countries (OECD, 2012). In order to take into account all the transitional restrictions, a much more detailed microlevel data set would be required. It is important, however, to note that having transitional restrictions in place does not mean nonexistent migration or job mobility; it simply means that migrants are required to go through bureaucratic immigration and job application procedures (European Commission, 2006b).

\section{Empirical and Identification Strategy}

\subsection{Identification strategy}

The paper's objective is to measure the causal effects of the 2004 EU expansion on migrants' labour market outcomes, i.e. full-time employment and income. The paper uses a DD estimation strategy to identify such causal effects. The first difference is along the time dimension, i.e. before and after the expansion. Two years of data are used, i.e. 2008 and 1999. These two years straddle the 2004 EU expansion year. The second difference compares migrants' and citizens' labour market outcomes. Citizens act as a suitable control group because they are unaffected by the EU expansion as they are already enjoying employment 
privileges due to their citizen status. As explained later, a more refined group of citizens will be selected as control group for the DD estimations. Therefore, the resident status (i.e. a citizen or a migrant) and the period (i.e. before or after the 2004 expansion) jointly determine an individual's exposure to the expansion's effects.

Table 1 illustrates the basic idea underlying the DD identification strategy. It shows the average full-time employment rate and average monthly household income of the citizen and migrant groups, before and after the EU expansion. The top panel compares the full-time employment rates of individuals with different resident status before and after the expansion. There are two types of differences, i.e. the difference in employment rates between migrants and citizens, and the difference in employment rates before and after the expansion takes place. The DD identification strategy entails taking the difference of these differences, i.e. an average of 0.05 percentage point increase in migrants' employment rates in the post-expansion period. Had the specification used citizens in general as the control group instead of highly skilled citizens, the simple mean difference of 0.05 would have been the same as the DD estimate (i.e. the estimated coefficient to the 'Post2004*Migrant' interaction variable for individuals with migrant status in the post-expansion period) obtained from the standard DD model in Specification 1 of Table 3.

Table 1 | Average Employment and Income

\begin{tabular}{|l|c|r|r|}
\hline & Pre-2004 & Post-2004 & Diff. (Post-Pre) \\
\hline \multicolumn{4}{|c|}{ Average Employment } \\
\hline \multirow{2}{*}{ Citizen } & 0.4008 & 0.4075 & 0.0067 \\
& $(0.0028)$ & $(0.0026)$ & $(0.0039)$ \\
\hline \multirow{2}{*}{ Migrant } & 0.4073 & 0.4640 & 0.0567 \\
& $(0.0143)$ & $(0.0148)$ & $(0.0205)$ \\
\hline \multirow{2}{*}{ Diff. (Migrant-Citizen) } & 0.0065 & 0.0565 & 0.0500 \\
& $(0.0145)$ & $(0.0148)$ & $(0.0208)$ \\
\hline \multicolumn{4}{|c|}{ Average Income } \\
\hline \multirow{2}{*}{ Citizen } & 0.3123 & -0.0783 & -0.3907 \\
& $(0.0054)$ & $(0.0051)$ & $(0.0075)$ \\
\hline \multirow{2}{*}{ Migrant } & 0.3813 & 0.4089 & 0.0276 \\
& $(0.0321)$ & $(0.0274)$ & $(0.0435)$ \\
\hline \multirow{2}{*}{ Diff. (Migrant-Citizen) } & 0.0689 & 0.4872 & 0.4183 \\
& $(0.0344)$ & $(0.0284)$ & $(0.0454)$ \\
\hline
\end{tabular}

Notes: Average employment figures are in units of full-time employment rates, while average income figures in log of monthly household income. Standard errors in parentheses.

Source: Author's model estimation based on EVS2008 and EVS1999 data sets.

The simple mean difference of 0.05 from Table 1 is interpreted as the causal effect of the EU expansion, under the assumption that in the absence of the expansion, the increase in migrants' employment rates would not have been systematically different from those of the citizens'. That is, the time trends in the absence of the expansion are the same in both groups. This is the key identifying assumption of the DD estimation strategy. The 2004 
EU expansion, which can be considered as a natural experiment, generates an exogenous variation for the labour market outcomes of those with migrant status, i.e. the expansion is an exogenous shock.

The lower panel of Table 1 shows that, relative to citizens, the logarithm of migrants' monthly household income is about 0.42 higher on average, after the EU expansion. While an increase in the logarithm of income is not exactly intuitive, its interpretation is useful when put in a regression context. As seen later in the standard DD model (Specification 1 of Table 4, Panel A), migrants see an approximate 33\% increase in their income, on average, after the EU expansion. The DD estimate of 0.33 would have been the same as the simple mean difference of 0.4183 in Table 1 had the standard DD model specification used citizens in general as the control group. The rationale for not using citizens in general as the control group in the DD estimations is explained in Section 4.1.

\subsection{DD estimation model}

The most basic DD model set-up consists of two periods and two groups and is valid if the key identifying assumption is fulfilled. As mentioned earlier, the identifying assumption is that changes in the outcome variable over time would have been exactly the same in both treated and control groups in the absence of treatment (Bertrand et al. 2004, p. 251). In the context of this paper, the treated group consists of migrants, while citizens make up the control group. The 2004 EU expansion is the 'treatment'. With a two-period pooled cross-sections, the standard DD model specification is written as follows.

$$
Y=\beta_{0}+\beta_{1} \text { Migrant }+\delta_{0} \text { Post } 2004+\delta_{1}(\text { Post } 2004 * \text { Migrant })+u,
$$

$Y$ is the labour market outcome, i.e. probability of full-time employment and monthly household income. The dummy variable Migrant captures differences between citizens and migrants prior to the EU expansion. The time period dummy variable Post2004 captures aggregate factors that would affect the $Y$ outcome even in the absence of the EU expansion. The interaction term, 'Post2004*Migrant', is a dummy variable which equals one for individuals with migrant status in the post-expansion period. Its coefficient of interest, $\delta_{1}$, is interpreted as the causal effect of the EU expansion on migrants' labour market outcomes. Extended versions of the model specification in Equation 1 can include additional vectors of control variables and/or fixed effects (FE). The extended DD model specification is expressed as follows.

$$
Y=\beta_{0}+\beta_{1} \text { Migrant }+\delta_{0} \text { Post } 2004+\delta_{1}(\text { Post } 2004 * \text { Migrant })+\alpha^{\prime} X+\phi+u .
$$

Vectors of control variables $X$ and fixed effects $\phi$ are included in Equation 2, as used in Specification (2) to (5) of Table 3 and 4. In both equations, the $i$ subscript for individual is intentionally left out to minimize notational clutter. 


\section{Results and Discussion}

\subsection{Summary statistics}

Table 2 reports some summary statistics for the labour market outcomes and selected characteristics of the citizen and migrant groups in pre- and post-expansion periods. These statistics come from the pooled cross-section EVS data set, with a total of 66,034 observations. The employment and income statistics here give some indicative evidence that migrants fare better after the EU expansion. Prior to the expansion, the magnitudes of monthly household income and the proportion of full-time employment between citizens and migrants are similarly close. In fact, the differences are statistically insignificant. The average monthly household income (in $€$ '000, corrected for purchasing power parity) for migrants increases from a pre-expansion $€ 1,778$ to a post-expansion $€ 2,448$, and their full-time employment proportion increases from an average of $40.7 \%$ to $46.4 \%$.

Although citizens in general (i.e. with all types of job skills) seem to be a natural control group in the DD model set-up, there might be concerns that due to the workings of general equilibrium, migrants' labour market outcomes are also affecting such citizens' labour market outcomes. In light of this, a more refined and perhaps a better control group would be highly skilled citizens. In principle, highly skilled citizens should not be affected or least affected by what is happening in the migrants' labour market due to the EU expansion, since the migrants are typically of lower skill levels. The use of such a narrowly defined control group is not unusual in program evaluation literature. For instance, in estimating the effects of workers' compensation (i.e. a raise in the benefit amount for high-earnings individuals) on how much time spent on compensation, Meyer et al. (1995) compared high-earners treatment group to low-earners control group. According to them, the control group should not be affected by the change in the cap on covered earnings. Therefore, in a similar vein, all analyses henceforth in this paper will use highly skilled citizens as the control group.

\subsection{DD estimation results on employment}

Table 3 shows the DD estimation results of how migrants' full-time employment chances or probabilities are affected by the expansion. Five model specifications are used. The estimate of interest is the estimate to the 'Post2004*Migrant' interaction variable. The magnitude of this estimate is the causal effect of the expansion on migrants' probabilities of having a full-time employment. Note that the estimates in Table 3 to Table 6 are marginal effects. In the most parsimonious Specification (1), this estimate is obtained from the DD basic model as in Equation 1 using the full sample (i.e. all ages, both male and female). A migrant's probability of having a full-time employment in the post-expansion period increases by 11.4 percentage points, on average. Had the control group been citizens in general instead of the highly skilled citizens used in the estimations here, the DD estimate from Specification (1) would have equaled the difference-in-differences mean proportions of employment in Table 1, i.e. 0.05 or 5 percentage points. Estimates for the other two regressors in the basic model of Equation (1), 'Post2004' and 'Migrant' are also reported. 
Table 2 | Summary Statistics

\begin{tabular}{|c|c|c|c|c|}
\hline & \multicolumn{2}{|c|}{1999} & \multicolumn{2}{|c|}{2008} \\
\hline & Citizen & Migrant & Citizen & Migrant \\
\hline \multicolumn{5}{|c|}{ Labour market outcomes } \\
\hline Monthly household income & $\begin{array}{c}1.714 \\
(1.208)\end{array}$ & $\begin{array}{c}1.778 \\
(1.181) \\
\end{array}$ & $\begin{array}{c}1.586 \\
(1.375)\end{array}$ & $\begin{array}{c}2.448 \\
(1.705)\end{array}$ \\
\hline Full-time employment & $\begin{array}{c}0.401 \\
(0.490)\end{array}$ & $\begin{array}{l}0.407 \\
(0.492)\end{array}$ & $\begin{array}{l}0.407 \\
(0.491)\end{array}$ & $\begin{array}{c}0.464 \\
(0.499)\end{array}$ \\
\hline \multicolumn{5}{|c|}{ Demographic variables } \\
\hline Male & $\begin{array}{c}0.464 \\
(0.498)\end{array}$ & $\begin{array}{c}0.498 \\
(0.500)\end{array}$ & $\begin{array}{c}0.442 \\
(0.496)\end{array}$ & $\begin{array}{c}0.476 \\
(0.499)\end{array}$ \\
\hline Female & $\begin{array}{c}0.535 \\
(0.499)\end{array}$ & $\begin{array}{c}0.502 \\
(0.500)\end{array}$ & $\begin{array}{c}0.557 \\
(0.497)\end{array}$ & $\begin{array}{c}0.523 \\
(0.500)\end{array}$ \\
\hline Married & $\begin{array}{c}0.566 \\
(0.495)\end{array}$ & $\begin{array}{c}0.516 \\
(0.499)\end{array}$ & $\begin{array}{c}0.535 \\
(0.498)\end{array}$ & $\begin{array}{c}0.505 \\
(0.500)\end{array}$ \\
\hline Single & $\begin{array}{c}0.237 \\
(0.425) \\
\end{array}$ & $\begin{array}{c}0.325 \\
(0.468) \\
\end{array}$ & $\begin{array}{c}0.250 \\
(0.433) \\
\end{array}$ & $\begin{array}{c}0.357 \\
(0.479) \\
\end{array}$ \\
\hline Age (Overall) & $\begin{array}{c}45.6 \\
(17.26)\end{array}$ & $\begin{array}{c}39.0 \\
(15.57)\end{array}$ & $\begin{array}{c}49.1 \\
(18.00)\end{array}$ & $\begin{array}{c}41.1 \\
(17.71)\end{array}$ \\
\hline Working age (18-65) & $\begin{array}{c}40.4 \\
(13.35) \\
\end{array}$ & $\begin{array}{c}36.8 \\
(12.28) \\
\end{array}$ & $\begin{array}{c}42.2 \\
(13.51)\end{array}$ & $\begin{array}{c}36.4 \\
(13.49) \\
\end{array}$ \\
\hline \multicolumn{5}{|c|}{ Education-related variables } \\
\hline Upper level education & $\begin{array}{c}0.202 \\
(0.401) \\
\end{array}$ & $\begin{array}{c}0.213 \\
(0.409) \\
\end{array}$ & $\begin{array}{c}0.249 \\
(0.433) \\
\end{array}$ & $\begin{array}{c}0.315 \\
(0.464) \\
\end{array}$ \\
\hline Middle level education & $\begin{array}{c}0.410 \\
(0.491)\end{array}$ & $\begin{array}{c}0.361 \\
(0.480)\end{array}$ & $\begin{array}{c}0.433 \\
(0.495)\end{array}$ & $\begin{array}{c}0.339 \\
(0.473)\end{array}$ \\
\hline Lower level education & $\begin{array}{c}0.395 \\
(0.488) \\
\end{array}$ & $\begin{array}{c}0.389 \\
(0.487) \\
\end{array}$ & $\begin{array}{c}0.333 \\
(0.471) \\
\end{array}$ & $\begin{array}{c}0.347 \\
(0.476) \\
\end{array}$ \\
\hline \multicolumn{5}{|c|}{ Job-related variables } \\
\hline High-skilled & $\begin{array}{c}0.262 \\
(0.439) \\
\end{array}$ & $\begin{array}{c}0.198 \\
(0.398) \\
\end{array}$ & $\begin{array}{c}0.306 \\
(0.461) \\
\end{array}$ & $\begin{array}{c}0.324 \\
(0.468)\end{array}$ \\
\hline Mid-skilled & $\begin{array}{c}0.072 \\
(0.258) \\
\end{array}$ & $\begin{array}{c}0.043 \\
(0.203)\end{array}$ & $\begin{array}{c}0.058 \\
(0.233)\end{array}$ & $\begin{array}{c}0.029 \\
(0.170)\end{array}$ \\
\hline Low-skilled & $\begin{array}{c}0.383 \\
(0.486) \\
\end{array}$ & $\begin{array}{c}0.384 \\
(0.487) \\
\end{array}$ & $\begin{array}{c}0.451 \\
(0.497) \\
\end{array}$ & $\begin{array}{c}0.454 \\
(0.498) \\
\end{array}$ \\
\hline Union membership & $\begin{array}{c}0.139 \\
(0.346)\end{array}$ & $\begin{array}{c}0.101 \\
(0.301)\end{array}$ & $\begin{array}{c}0.110 \\
(0.313)\end{array}$ & $\begin{array}{c}0.086 \\
(0.281)\end{array}$ \\
\hline Number of observations, $\mathbf{N}$ & 29,508 & 1,176 & 34,210 & 1,140 \\
\hline
\end{tabular}

Notes: Summary statistics are in proportions, except for income and age. Standard deviations in parentheses.

Source: EVS2008 and EVS1999 data sets. 
Table 3 | DD Estimations of EU Expansion Effects on Employment

\begin{tabular}{|l|c|c|c|c|c|}
\hline \multirow{2}{*}{$\begin{array}{l}\text { Dependent Variable: } \\
\text { In full-time employment }\end{array}$} & \multicolumn{5}{|c|}{ Specifications } \\
\cline { 2 - 6 } Post2004*Migrant & $\begin{array}{c}0.114^{* * *} \\
(0.022)\end{array}$ & $\begin{array}{c}0.126^{* * *} \\
(0.029)\end{array}$ & $\begin{array}{c}0.076^{* *} \\
(0.031)\end{array}$ & $\begin{array}{c}0.136^{* * * *} \\
(0.034)\end{array}$ & $\begin{array}{c}0.077^{* *} \\
(0.032)\end{array}$ \\
\hline Post2004 & $\begin{array}{c}-0.057^{* * *} \\
(0.007)\end{array}$ & $\begin{array}{c}-0.017 \\
(0.010)\end{array}$ & $\begin{array}{c}-0.025^{*} \\
(0.014)\end{array}$ & $\begin{array}{c}-0.015 \\
(0.011)\end{array}$ & $\begin{array}{c}-0.025^{* *} \\
(0.010)\end{array}$ \\
\hline Migrant & $-0.154^{* * *}$ & -0.018 & -0.010 & -0.031 & -0.005 \\
$(0.015)$ & $(0.032)$ & $(0.027)$ & $(0.035)$ & $(0.035)$ \\
\hline $\mathbf{R}^{2}$ & 0.006 & 0.175 & 0.217 & 0.193 & 0.226 \\
\hline Number of observations, N & 20,532 & 7,931 & 7,681 & 7,931 & 7,681 \\
\hline Controls & & $\checkmark$ & $\checkmark$ & $\checkmark$ & $\checkmark$ \\
\hline Job type FE/dummies & & & $\checkmark$ & & $\checkmark$ \\
\hline Age cohort FE/dummies & & & & $\checkmark$ & $\checkmark$ \\
\hline
\end{tabular}

Notes: In Table 3 to Table 6, the following applies - (i) highly skilled citizens are used as control group, (ii) estimates are marginal effects, (iii) standard errors in parentheses, and (iv) significance levels represented as ${ }^{* * *} 1 \%,{ }^{*} 5 \%$, and ${ }^{*} 10 \%$. Specification (1) is estimated using the full sample, i.e. all ages for both male and female. Specifications (2) to (5) used the working-age male subsample.

Source: Author's model estimation based on EVS2008 and EVS1999 data sets.

The working-age (between 18 and 65) male subsample is used for estimations in Specification (2) to (5). For the working-age female subsample, the DD coefficient of interest is statistically insignificant in all five specifications and therefore not reported. Specifications (2) to (5) include controls, job type and/or age cohort fixed effects (FE), i.e. dummies for each job type and age cohort. The controls include demographic, education-related, and job-related variables, i.e. as listed in Table 2. The inclusion of controls accounts for the possibilities that population samples may differ systematically over the two time periods.

By incorporating $\mathrm{FE}$, it captures time-invariant individual-specific unobserved heterogeneity. If unaccounted for, such unobserved heterogeneity could lead to omitted variable bias. The job type FE accounts for unobserved job aspects such as unpleasantness or riskiness. The job type FE can be plausibly deemed constant over time and within job types, but different across job types. Similarly, the age cohort FE picks up the effect of unobservable across-cohort heterogeneity that makes an age cohort unique. A year FE would have been more suitable, but this is not possible with a two-year data set. This is why the age cohort FE is used, to incorporate some aspects of time-related FE. The job type FE is used instead of country FE (which can be that of the host or home country) because there are more variations in job types. It is also plausible that certain types of jobs are typical for, say, migrants from a particular country. Controlling for job type FE would have, to a certain extent, already encompassed country FE as well. Take for example, the 'Polish Plumber' phenomenon; it typically refers to migrants coming from East European countries to work in stereotypical construction jobs. 
Following Bertrand et al. (2004) in using clustered errors, Specification (3) to (5) allow for intragroup correlation. If unaccounted for, it could lead to standard errors being underestimated. The standard errors in Specification (3) to (5) in Table 3 and 4 are therefore adjusted for clusters at the job type and/or age cohort level. It is likely that the errors are correlated within clusters or groups (i.e. job type or age cohort), but not across groups. Specification (5), with the most extensive set of controls and fixed effects, is the main DD estimation specification of this paper. The probability of having a full-time employment for a male migrant in the post-expansion period increases by about 7.7 percentage points, on average.

\subsection{DD estimation results on income}

Table 4 shows the DD estimation results of how the 2004 EU expansion affects migrants' income. Prior to estimation, the nominal incomes reported by the respondents in the two EVS2008 and EVS1999 surveys have been adjusted to real income by using the Consumer Price Index for 2000 as base year. Table 4 contains three result panels, with Panel A showing results for both males and females, before splitting them in Panel B and C. For completeness purpose and robustness check, the DD estimation results are again reported using the five specifications as in Table 3. The main specification here is again Specification (5), with the DD estimate for the 'Post 2004 *Migrant' variable being the estimate of interest. Note that the DD estimates are highly significant throughout different specifications and full/subsamples. The DD estimates are also consistently larger in magnitude for the male subsample than the female subsample.

The dependent variable is the natural logarithm of real monthly household income, so that percentage interpretation can be used. From Specification (5), migrants see an increase of about $21.8 \%$ in their monthly household income after the EU expansion. When the estimations are broken down by gender, we see that male migrants experience a higher increase in their income (22.8\%) compared to female migrants (19.1\%) after the EU expansion. On a related note, the results (unreported here; available upon request) of the DD estimate for the 'Post2004*Migrant' variable of interest are mainly driven by the EU15 subsample, rather than the EU9 subsample. That is, if we were to break down EU24 into its old (EU15) and new (EU9) members, we would find statistically significant DD estimate for the 'Post2004*Migrant' variable on both employment and income for the EU15 subsample only. Such results are not surprising because migrants are known to typically move from the new EU9 to the old EU15 countries in search of better employment and income.

Since income has a continuous distribution, quantile regressions can reveal underlying patterns which are undetectable by typical mean regressions. Quantile regressions examine features of the income distribution besides the mean. Table 5 reports quantile regression estimates for the $0.1,0.25,0.5,0.75$, and 0.9 quantiles. Estimation results for the male and female subsamples are obtained using Specification (5). Male migrants at the lowest 0.1 quantile of the income distribution fare best; their income increases by about $35.6 \%$ after the EU expansion. For both male and female migrants, (i) the expansion has a much larger positive impact on the income at the lower quantiles, and (ii) the expansion does not have any impact on the income at the highest 0.9 quantile. The magnitude of the DD 
estimates (i.e. the estimates of Post2004*Migrant) shows that the EU expansion results in higher income increase for male migrants compared to their female counterparts for every quantile of the income distribution. There are probably concerns over the seemingly large magnitude of the income increase. It is, however, not uncommon to obtain such magnitudes. For instance, simulation results by Elsner (2013) showed that the 2004 EU expansion contributed between $10 \%$ and $30 \%$ of the changes wage. Note also that the outcome variable used in this current paper is household income, and not wages per se. Therefore it may have included some other forms of income other than the wages of the respondents.

Table 4 | DD Estimation Result for EU Expansion Effects on Income

\begin{tabular}{|c|c|c|c|c|c|}
\hline \multirow{2}{*}{$\begin{array}{l}\text { Dependent Variable: } \\
\text { Log of real monthly } \\
\text { household income }\end{array}$} & \multicolumn{5}{|c|}{ Specifications } \\
\hline & (1) & (2) & (3) & (4) & (5) \\
\hline \multicolumn{6}{|c|}{ Panel A: Full sample } \\
\hline Post2004*Migrant & $\begin{array}{l}0.330 * * * \\
(0.044)\end{array}$ & $\begin{array}{l}0.254^{* * *} \\
(0.037)\end{array}$ & $\begin{array}{l}0.207^{* * *} \\
(0.047)\end{array}$ & $\begin{array}{l}0.246^{* * *} \\
(0.055)\end{array}$ & $\begin{array}{l}0.218^{* * * *} \\
(0.045)\end{array}$ \\
\hline Post2004 & $\begin{array}{l}-0.302^{* * *} \\
(0.013)\end{array}$ & $\begin{array}{c}-0.260^{* * *} \\
(0.011)\end{array}$ & $\begin{array}{c}-0.264^{* * *} \\
(0.014)\end{array}$ & $\begin{array}{c}-0.260^{* * *} \\
(0.013)\end{array}$ & $\begin{array}{c}-0.264^{* * *} \\
(0.010)\end{array}$ \\
\hline Migrant & $\begin{array}{c}-0.152^{* * *} \\
(0.035)\end{array}$ & $\begin{array}{l}-0.066 \\
(0.042)\end{array}$ & $\begin{array}{l}-0.038 \\
(0.046)\end{array}$ & $\begin{array}{l}-0.057 \\
(0.050)\end{array}$ & $\begin{array}{l}-0.048 \\
(0.047)\end{array}$ \\
\hline $\mathbf{R}^{2}$ & 0.033 & 0.369 & 0.386 & 0.371 & 0.389 \\
\hline Number of observations, $\mathrm{N}$ & 15,389 & 12,610 & 12,341 & 12,610 & 12,341 \\
\hline \multicolumn{6}{|c|}{ Panel B: Male subsample } \\
\hline Post2004* Migrant & $\begin{array}{l}0.383^{* * * *} \\
(0.060)\end{array}$ & $\begin{array}{l}0.315^{* * * *} \\
(0.054)\end{array}$ & $\begin{array}{l}0.241 * * * \\
(0.082)\end{array}$ & $\begin{array}{l}0.304^{* * * *} \\
(0.068)\end{array}$ & $\begin{array}{l}0.228^{* * * *} \\
(0.066)\end{array}$ \\
\hline Post2004 & $\begin{array}{c}-0.298^{* * * *} \\
(0.017)\end{array}$ & $\begin{array}{c}-0.275^{* * *} \\
(0.016)\end{array}$ & $\begin{array}{c}-0.286^{* * *} \\
(0.020)\end{array}$ & $\begin{array}{c}-0.275^{* * *} \\
(0.017)\end{array}$ & $\begin{array}{c}-0.285^{* * *} \\
(0.015)\end{array}$ \\
\hline Migrant & $\begin{array}{c}-0.259 * * * \\
(0.047)\end{array}$ & $\begin{array}{c}-0.103^{*} \\
(0.060)\end{array}$ & $\begin{array}{l}-0.061 \\
(0.066)\end{array}$ & $\begin{array}{l}-0.092 \\
(0.063)\end{array}$ & $\begin{array}{r}-0.053 \\
(0.065)\end{array}$ \\
\hline $\mathbf{R}^{2}$ & 0.036 & 0.296 & 0.321 & 0.302 & 0.326 \\
\hline Number of observations, $\mathrm{N}$ & 7,472 & 5,980 & 5,877 & 5,980 & 5,877 \\
\hline \multicolumn{6}{|c|}{ Panel C: Female subsample } \\
\hline Post2004* Migrant & $\begin{array}{l}0.262^{* * *} \\
(0.065)\end{array}$ & $\begin{array}{l}0.196^{* * *} \\
(0.052)\end{array}$ & $\begin{array}{l}0.165^{* * * *} \\
(0.059)\end{array}$ & $\begin{array}{l}0.185^{* * *} \\
(0.063)\end{array}$ & $\begin{array}{l}0.191^{* * *} \\
(0.062)\end{array}$ \\
\hline Post2004 & $\begin{array}{c}-0.286^{* * *} \\
(0.019)\end{array}$ & $\begin{array}{c}-0.247^{* * *} \\
(0.015)\end{array}$ & $\begin{array}{c}-0.247^{* * *} \\
(0.020)\end{array}$ & $\begin{array}{c}-0.248^{* * *} \\
(0.018)\end{array}$ & $\begin{array}{c}-0.247^{* * *} \\
(0.016)\end{array}$ \\
\hline Migrant & $\begin{array}{l}-0.040 \\
(0.052)\end{array}$ & $\begin{array}{l}-0.027 \\
(0.059)\end{array}$ & $\begin{array}{l}-0.006 \\
(0.052)\end{array}$ & $\begin{array}{l}-0.021 \\
(0.064)\end{array}$ & $\begin{array}{l}-0.028 \\
(0.069)\end{array}$ \\
\hline $\mathbf{R}^{2}$ & 0.029 & 0.408 & 0.423 & 0.412 & 0.428 \\
\hline Number of observations, $\mathrm{N}$ & 7,917 & 6,630 & 6,464 & 6,630 & 6,464 \\
\hline Controls & & $\checkmark$ & $\checkmark$ & $\checkmark$ & $\checkmark$ \\
\hline Job type FE/dummies & & & $\checkmark$ & & $\checkmark$ \\
\hline Age cohort FE/dummies & & & & $\checkmark$ & $\checkmark$ \\
\hline
\end{tabular}

Notes: The nominal incomes reported by the respondents in the two EVS2008 and EVS1999 surveys have been adjusted to real income by using the Consumer Price Index for 2000 as base year. Specification (1) is estimated for all ages. Specifications (2) to (5) used the working-age subsample.

Source: Author's model estimation based on EVS2008 and EVS1999 data sets. 
Table 5 | DD Estimation Result for EU Expansion Effects on Income by Quantile

\begin{tabular}{|c|c|c|c|c|c|}
\hline \multirow{2}{*}{$\begin{array}{l}\text { Dependent Variable: } \\
\text { Log of real monthly } \\
\text { household income }\end{array}$} & \multicolumn{5}{|c|}{ Income quantile } \\
\hline & 0.1 & 0.25 & 0.5 & 0.75 & 0.9 \\
\hline \multicolumn{6}{|c|}{ Panel A: Male subsample } \\
\hline Post2004* Migrant & $\begin{array}{l}0.356^{* * *} \\
(0.084)\end{array}$ & $\begin{array}{l}0.297^{* * *} \\
(0.063)\end{array}$ & $\begin{array}{l}0.306^{* * *} \\
(0.053)\end{array}$ & $\begin{array}{l}0.241^{* * *} \\
(0.079)\end{array}$ & $\begin{array}{c}0.114 \\
(0.086)\end{array}$ \\
\hline Post2004 & $\begin{array}{c}-0.284^{* * *} \\
(0.025)\end{array}$ & $\begin{array}{c}-0.278^{* * *} \\
(0.017)\end{array}$ & $\begin{array}{l}-0.274^{* * *} \\
(0.014)\end{array}$ & $\begin{array}{c}-0.292^{* * *} \\
(0.017)\end{array}$ & $\begin{array}{c}-0.238^{* * *} \\
(0.021)\end{array}$ \\
\hline Migrant & $\begin{array}{c}-0.218^{*} \\
(0.124)\end{array}$ & $\begin{array}{l}-0.093 \\
(0.076)\end{array}$ & $\begin{array}{l}-0.094 \\
(0.065)\end{array}$ & $\begin{array}{l}-0.012 \\
(0.083)\end{array}$ & $\begin{array}{c}0.029 \\
(0.078)\end{array}$ \\
\hline \multicolumn{6}{|c|}{ Panel B: Female subsample } \\
\hline Post2004* Migrant & $\begin{array}{c}0.187 \\
(0.128) \\
\end{array}$ & $\begin{array}{l}0.277^{* *} \\
(0.130) \\
\end{array}$ & $\begin{array}{l}0.178^{* *} \\
(0.088)\end{array}$ & $\begin{array}{c}0.137 \\
(0.093) \\
\end{array}$ & $\begin{array}{c}0.078 \\
(0.093) \\
\end{array}$ \\
\hline Post2004 & $\begin{array}{c}-0.285^{* * *} \\
(0.029)\end{array}$ & $\begin{array}{c}-0.303^{* * *} \\
(0.018)\end{array}$ & $\begin{array}{c}-0.268^{* * *} \\
(0.015)\end{array}$ & $\begin{array}{c}-0.226^{* * *} \\
(0.020)\end{array}$ & $\begin{array}{c}-0.175^{* * *} \\
(0.018)\end{array}$ \\
\hline Migrant & $\begin{array}{l}-0.079 \\
(0.083)\end{array}$ & $\begin{array}{l}-0.060 \\
(0.083)\end{array}$ & $\begin{array}{l}-0.006 \\
(0.077)\end{array}$ & $\begin{array}{c}0.001 \\
(0.081)\end{array}$ & $\begin{array}{c}0.035 \\
(0.105)\end{array}$ \\
\hline
\end{tabular}

Source: Author's model estimation based on EVS2008 and EVS1999 data sets.

\subsection{DD validity check}

In DD estimations, one common way to check whether it is really the said effect that is actually bringing the changes in the post-intervention period, is to change the period threshold to a cut-off year within the pre-intervention period. This is known as a placeboyear test, and regarded as a standard validity check to test an implication of the DD estimation's key identifying assumption. Using placebo years as alternative threshold years should not give statistically significant DD estimates. If it does, it means there are other events happening in those years that are affecting the estimates, thereby undermining the validity of the DD estimation. This current study, however, has only two time periods, i.e. a year of data each for the period before and after the EU expansion. It is therefore not possible to do a placebo-year test here. Nevertheless, some other versions of validity checks are still doable.

Table 6 shows the results from two validity checks. The first validity check uses only pre-2004 observations from the working data set (i.e. the data set used for all estimations prior to this). In using only pre-2004 observations, however, the standard DD estimation model in Equation 1 is no longer relevant. Instead, the DD estimation model is now expressed as follows.

$$
Y=\beta_{0}+\beta_{1} \text { Migrant }+\delta_{0} \text { EU15 }+\delta_{1}(\text { EU15 } * \text { Migrant })+u .
$$

Here, the DD estimate of interest is the coefficient to the 'EU15*Migrant' interaction variable. The control group consists of citizens and migrants in EU9 countries. The idea is that, if the 2004 EU expansion does indeed have an impact on the labour market outcomes 
of migrants working in EU15 countries, then the DD estimate here should not be statistically significant in the pre-2004 period. As seen from Panel A of Table 6, the DD estimates are either insignificant or only marginally significant at the $10 \%$ level. The estimates are also statistically insignificant in the main Specification (5). The results imply that, before the expansion, migrants in EU15 countries do not experience any significant increases in their employment probabilities or income. In a way, results from the first validity check suggest no evidence of any obvious phenomenon that is affecting migrants' labour market outcomes.

Panel B of Table 6 shows the DD estimation results of the second validity check. For this check, a slightly different data set is used. As before, the two EVS2008 and EVS1999 data sets are merged, but citizens and migrants in the EU25 countries (i.e. EU10 and EU15 countries) are dropped. The merged data set contains only citizens and migrants in the remaining non-EU25 countries. The standard DD estimation model for this check is the same as in Equation (1). The idea here is that, if it is really the EU expansion that is driving the migrants' labour market outcomes, then the expansion should only affect the outcomes in EU countries. The EU expansion should not have any significant impact on migrants' labour market outcomes in non-EU countries. The statistically insignificant DD estimates (for both employment and income) in Panel B give evidence to support this argument. Results from the two validity checks suggest that the DD estimations used in this paper to be valid, and should therefore be adequately credible. 
Table 6 | DD Validity Check

\begin{tabular}{|c|c|c|c|c|c|}
\hline & \multicolumn{5}{|c|}{ Specifications } \\
\hline & (1) & (2) & (3) & (4) & (5) \\
\hline \multicolumn{6}{|c|}{ Panel A: Validity Check 1} \\
\hline \multicolumn{6}{|c|}{ Dependent variable: Employment } \\
\hline EU15*Migrant & $\begin{array}{c}0.112^{*} \\
(0.062)\end{array}$ & $\begin{array}{c}0.105^{*} \\
(0.062)\end{array}$ & $\begin{array}{c}0.037 \\
(0.089)\end{array}$ & $\begin{array}{c}0.097 \\
(0.068) \\
\end{array}$ & $\begin{array}{c}0.017 \\
(0.075) \\
\end{array}$ \\
\hline EU15 & $\begin{array}{l}-0.086^{* * *} \\
(0.011)\end{array}$ & $\begin{array}{c}-0.137^{* * *} \\
(0.011)\end{array}$ & $\begin{array}{c}-0.123^{* * *} \\
(0.024)\end{array}$ & $\begin{array}{c}-0.134^{* * *} \\
(0.011)\end{array}$ & $\begin{array}{c}-0.125^{* * *} \\
(0.011)\end{array}$ \\
\hline Migrant & $\begin{array}{c}-0.235^{* * *} \\
(0.060)\end{array}$ & $\begin{array}{l}-0.113^{*} \\
(0.065)\end{array}$ & $\begin{array}{l}-0.063 \\
(0.084) \\
\end{array}$ & $\begin{array}{l}-0.111 \\
(0.075) \\
\end{array}$ & $\begin{array}{l}-0.046 \\
(0.079) \\
\end{array}$ \\
\hline $\mathbf{R}^{2}$ & 0.017 & 0.166 & 0.180 & 0.182 & 0.187 \\
\hline Number of observations, $\mathrm{N}$ & 8920 & 7,751 & 7,361 & 7,751 & 7,361 \\
\hline \multicolumn{6}{|l|}{ Dependent variable: Income } \\
\hline EU15* Migrant & $\begin{array}{c}0.279 \\
(0.239)\end{array}$ & $\begin{array}{c}0.213 \\
(0.234)\end{array}$ & $\begin{array}{c}0.104 \\
(0.155)\end{array}$ & $\begin{array}{c}0.211 \\
(0.153) \\
\end{array}$ & $\begin{array}{c}0.079 \\
(0.153)\end{array}$ \\
\hline EU15 & $\begin{array}{l}0.953^{* * *} \\
(0.144) \\
\end{array}$ & $\begin{array}{l}0.915^{* * *} \\
(0.134)\end{array}$ & $\begin{array}{l}0.911^{* * *} \\
(0.023)\end{array}$ & $\begin{array}{l}0.920 * * * \\
(0.021) \\
\end{array}$ & $\begin{array}{l}0.909 * * * \\
(0.018)\end{array}$ \\
\hline Migrant & $\begin{array}{c}-0.654 * * \\
(0.236)\end{array}$ & $\begin{array}{l}-0.355 \\
(0.259)\end{array}$ & $\begin{array}{c}-0.259 * \\
(0.146)\end{array}$ & $\begin{array}{c}-0.369^{* *} \\
(0.158)\end{array}$ & $\begin{array}{l}-0.240 \\
(0.164)\end{array}$ \\
\hline $\mathbf{R}^{2}$ & 0.368 & 0.454 & 0.467 & 0.465 & 0.472 \\
\hline Number of observations, $\mathbf{N}$ & 6,019 & 5,199 & 5,032 & 5,199 & 5032 \\
\hline \multicolumn{6}{|c|}{ Panel B: Validity Check 2} \\
\hline \multicolumn{6}{|c|}{ Dependent variable: Employment } \\
\hline Post2004* Migrant & $\begin{array}{c}0.106 \\
(0.087) \\
\end{array}$ & $\begin{array}{c}0.143 \\
(0.141) \\
\end{array}$ & $\begin{array}{c}0.156 \\
(0.112) \\
\end{array}$ & $\begin{array}{c}0.151 \\
(0.106) \\
\end{array}$ & $\begin{array}{c}0.153 \\
(0.095) \\
\end{array}$ \\
\hline Post2004 & $\begin{array}{c}-0.102^{* * *} \\
(0.013) \\
\end{array}$ & $\begin{array}{c}-0.080^{* *} \\
(0.035) \\
\end{array}$ & $\begin{array}{c}-0.089^{* * *} \\
(0.014) \\
\end{array}$ & $\begin{array}{l}-0.082^{* * *} \\
(0.015) \\
\end{array}$ & $\begin{array}{c}-0.089 * * * \\
(0.014) \\
\end{array}$ \\
\hline Migrant & $\begin{array}{c}-0.284^{* * *} \\
(0.085)\end{array}$ & $\begin{array}{r}-0.146 \\
(0.141) \\
\end{array}$ & $\begin{array}{l}-0.162 \\
(0.114) \\
\end{array}$ & $\begin{array}{l}-0.147 \\
(0.101) \\
\end{array}$ & $\begin{array}{c}-0.157^{*} \\
(0.094)\end{array}$ \\
\hline $\mathbf{R}^{2}$ & 0.018 & 0.087 & 0.101 & 0.093 & 0.110 \\
\hline Number of observations, $\mathrm{N}$ & 10,087 & 8,045 & 7,864 & 8,045 & 7,864 \\
\hline \multicolumn{6}{|l|}{ Dependent variable: Income } \\
\hline Post2004* Migrant & $\begin{array}{c}0.268 \\
(0.411) \\
\end{array}$ & $\begin{array}{c}0.053 \\
(0.420) \\
\end{array}$ & $\begin{array}{c}0.522 \\
(0.412) \\
\end{array}$ & $\begin{array}{c}0.057 \\
(0.339) \\
\end{array}$ & $\begin{array}{c}0.451 \\
(0.411) \\
\end{array}$ \\
\hline Post2004 & $\begin{array}{c}-0.815^{* * *} \\
(0.040) \\
\end{array}$ & $\begin{array}{c}-0.789 * * * \\
(0.040) \\
\end{array}$ & $\begin{array}{c}-0.647^{* * *} \\
(0.080) \\
\end{array}$ & $\begin{array}{c}-0.797^{* * *} \\
(0.045) \\
\end{array}$ & $\begin{array}{c}-0.647^{* * *} \\
(0.040) \\
\end{array}$ \\
\hline Migrant & $\begin{array}{l}-0.215 \\
(0.408)\end{array}$ & $\begin{array}{c}0.501 \\
(0.422)\end{array}$ & $\begin{array}{c}0.034 \\
(0.422)\end{array}$ & $\begin{array}{c}0.491 \\
(0.354) \\
\end{array}$ & $\begin{array}{c}0.098 \\
(0.410) \\
\end{array}$ \\
\hline $\mathbf{R}^{2}$ & 0.047 & 0.107 & 0.141 & 0.113 & 0.146 \\
\hline Number of observations, $\mathrm{N}$ & 8,216 & 7,178 & 6,996 & 7,178 & 6,996 \\
\hline Controls & & $\checkmark$ & $\checkmark$ & $\checkmark$ & $\checkmark$ \\
\hline Job type FE/dummies & & & $\checkmark$ & & $\checkmark$ \\
\hline Age cohort FE/dummies & & & & $\checkmark$ & $\checkmark$ \\
\hline
\end{tabular}

subsampie. ciusterea stanaara errors are computea tor specitication ( 3 ) to (b), clusterea at the job type and/or age cohort level. The first validity check in Panel A uses only pre-2004 observations from the paper's working data set. The second validity check in Panel B uses a differently constructed data set, which only includes citizens and immigrants in non-EU25 European countries.

Source: Author's model estimation based on EVS2008 and EVS1999 data sets. 


\section{Concluding Remarks}

This paper pooled two data sets from the 2008 and 1999 European Values Study, and used a DD identification strategy to estimate the causal effects of the $2004 \mathrm{EU}$ expansion on migrants' employment and income. Results from the DD estimations suggest that the 2004 EU expansion indeed brings some cheers to the migrants in terms of increased employment chances and income. Using the most extensive model specification that takes into account a set of controls, fixed effects and standard error clustering, estimation results suggest that the probability of having a full-time employment for a male migrant in the post EU expansion period increases by about 7.7 percentage points. The expansion effect on female migrants' employment probability is, however, insignificant. The increase in income for male migrants is $3.7 \%$ higher than that of their female counterparts after the expansion. When the income distribution is broken down into quantiles, estimation results show that male migrants at the lower ends of the income distribution experience higher increase in income. At the highest end of the income distribution, there is no evidence that the EU expansion has any significant impact on either the male or female migrants' income.

By using different model specifications and applying two validity checking measures, the estimation results here should be rigorous and credible enough, given the data limitation. Estimations from this paper can nevertheless be further improved if given data were with (i) more details at the household or individual level, and (ii) more than two years of data. With better data sets, possible future research avenues include examining the causal effects of the EU expansion on some other aspects of the migrants' labour market outcomes, such as (i) their labour supply in terms of working hours, (ii) changes in job prestige, (iii) the amount of welfare benefit received, and (iv) the duration of unemployment.

\section{References}

Bauer, T. K., Zimmermann, K. F. (1999). Assessment of Possible Migration Pressure and Its Labour Market Impact Following EU Enlargement to Central and Eastern Europe. Institute for the Study of Labor (IZA). Discussion Paper No. 3.

Bräuninger, D., Majowski, C. (2011). Labour Mobility in the Euro Area. Deutsche Bank Research Report on European Integration - EU Monitor 85. Frankfurt: Deutsche Bank AG.

Bertrand, M., Duflo, E., Mullainathan, S. (2004). How much Should We Trust Differences-in-Differences Estimates? The Quarterly Journal of Economics, 119(1), 249-275, http://doi.org/10.3386/w8841

Blanchflower, D. G., Lawton, H. (2008). The Impact of the Recent Expansion of the EU on the UK Labour Market. Institute for the Study of Labor (IZA). Discussion Paper No. 3695, http://doi.org/10.1007/978-3-642-02242-5_8

Braakmann, N., Vogel, A. (2010). The Impact of the 2004 EU Enlargement on the Performance of Service Enterprises in Germany's Eastern Border Region. Review of World Economics, 146(1), 75-89, http://doi.org/10.1007/s10290-009-0042-1

Brakman, S., Garretsen, H., van Marrewijk, C., Oumer, A. (2012). The Border Population Effects of EU Integration. Journal of Regional Science, 52(1), 40-59, http://doi. org/10.1111/j.1467-9787.2011.00752.x 
Buettner, T., Rincke, J. (2007). Labor Market Effects of Economic Integration: The Impact of Re-Unification in German Border Regions. German Economic Review, 8(4), 536-560, http://doi.org/10.1111/j.1468-0475.2007.00417.x

Card, D. (1990). The Impact of the Mariel Boatlift on the Miami Labor-Market. Industrial \& Labor Relations Review, 43(2), 245-257, http://doi.org/10.2307/2523702

Dobson, J. R. (2009). Labour Mobility and Migration within the EU Following the 2004 Central and East European Enlargement. Employee Relations, 31(2), 121-138, http://doi.org/10.1108/01425450910925283

Drinkwater, S., Eade, J., Garapich, M. (2009). Poles Apart? EU Enlargement and the Labour Market Outcomes of Immigrants in the United Kingdom. International Migration, 47(1), 161-190, http://doi.org/10.1111/j.1468-2435.2008.00500.x

Dustmann, C., Frattini, T. (2011). Immigration: The European Experience. Milan Centro Studi Luca D’Agliano. Development Studies Working Papers No. 326, http://doi.org/10.2139/ssrn.2023575

Elsner, B. (2013). Emigration and Wages: The EU Enlargement Experiment. Journal of International Economics, 91(1), 154-163, http://doi.org/10.1016/j.jinteco.2013.06.002

European Commission (2009). Five Years of an Enlarged EU: Economic Achievements and Challenges. Luxembourg: European Commission.

European Commission (2006a). Enlargement, Two Years After: an Economic Evaluation. Brussels: European Commission.

European Commission (2006b). Report on the Functioning of the Transitional Arrangements Set Out in the 2003 Accession Treaty (Period 1 May 2004-30 April 2006). Brussels: European Communities.

Koehler, J., Laczko, F., Aghazarm, C., Schad, J. (2010). Migration and the Economic Crisis in the European Union: Implications for Policy. Brussels: International Organization for Migration (IOM).

Mastrobuoni, G., Pinotti, P. (2011). Migration Restrictions and Criminal Behavior: Evidence from a Natural Experiment. Fondazione Eni Enrico Mattei. Milan Working Paper No. 53.2011, http://doi.org/10.2139/ssrn.1891689

Meyer, B. D., Viscusi, W. K., Durbin, D. L. (1995). Workers' Compensation and Injury Duration: Evidence from a Natural Experiment. The American Economic Review, 85(3), 322-340.

OECD (2012). OECD Economic Surveys: European Union. Paris: OECD Publishing, https://doi.org/10.1787/eco_surveys-eur-2012-en

Papademetriou, D. G., Sumption, M., Terrazas, A. (2010). Migration and Immigrants Two Years After the Financial Collapse: Where Do We Stand? Washington, DC: Migration Policy Institute.

Pedersen, P. J., Pytlikova, M. (2008). EU Enlargement: Migration Flows from Central and Eastern Europe into the Nordic Countries - Exploiting a Natural Experiment. Aarhus University Department of Economics. Working Paper No. 08-29.

Pytlikova, M. (2014). The Effect of EU Enlargements and Labour Market Openings on Migration. VSB-Technical University of Ostrava. Working Paper. 